\title{
Modern Indonesian Literature with Islamic Perspective
}

\author{
Ahmad Bahtiar ${ }^{1}$, Herman J. Waluyo ${ }^{2}$, Sarwiji Suwandi ${ }^{3}$ and Budhi Setiawan ${ }^{4}$ \\ \{ahmadbahtiar@student.uns.ac.id. ahmad.bahtiar@uinjtk.ac.id\} \\ 1234 Universitas Sebelas Maret, Surakarta \\ ${ }^{1}$ UIN Syarif Hidayatullah, Jakarta
}

\begin{abstract}
In the realm of modern Indonesian literature, there are several writers who write literary works about religious life, especially Islam, both as a background and as a problem solver for life. With the increasing number of such works, it is necessary to form a solid foundation that can be used as a conception of the theory. For this reason, this research aims to develop a theoretical framework on modern Indonesian literature with an Islamic perspective. By gathering various libraries, this qualitative descriptive study tries to reveal the perspective of Islam in modern Indonesian literature. Based on the sources obtained, this research reveals the concept of modern Indonesian literature with an Islamic perspective that covers the boundaries, scope, and background of the author. The findings of this study are expected to provide a solid contribution as the literary foundation of this genre and a reference to how readers can understand this literary work.
\end{abstract}

Keywords: modern Indonesian literature, Islam, qualitative, literature research

\section{Introduction}

Literature and religion have good relations and are quite clear. Atmosuwito said that the Holy Qur'an besides containing the sacred writings of the Islamic religion, also contained literary writings. Similarly, other holy books such as the Bible and Bhagawat Gita are also said to be poetry books and wisdom literature. Thus, it can be said that religious books are literature and literature is part of religion [1] and at the beginning, all literature is religious [2].

In the realm of Indonesian literature, both in the classical and modern periods, aesthetic images related to religion and beliefs that are spiritual and mystical, or spiritual, and religious messages as well as various things that become the main issue of religion, always appear in a variety of forms. When Islam entered the archipelago, the idea of Islamic religious literature was born and developed along with the spread of that religion through coastal regions. Malay Literature and Javanese Literature can at least be seen as the initial representation of the creation of Islamic literary ideas in the archipelago [3]. Through Under Di Bawah Lindungan Kabah (1938) and Tengggelamya Kapal van Der Wijk (1939) and Ship, Hamka wrote stories that emphasized religious life, in this case Islam as a background. Before Hamka, Suman Hasibuan wrote the Percobaan Setia (1931), stories about the pilgrims including a trip to the main character's holy land. Long before, the Popular Malay literary author G. Francis in 
Njerita Nyai Dasima (1896) and H. Mukti in the Hikayat Siti Mariah, which was first published as a sequel story in Medan Priyayi Daily, di Bandung between 1910-1912, wrote a story that raised questions about Islam and not Islam in his work.

This literary genre in the 1960s was confirmed by other authors such as Fridolin Ukur, Muhammad Diponegoro, and Djamil Suherman [4]. Later, especially after entering the decade of the 1970s, authors known to the 70s as Abdul Hadi, D. Zamawi Imron, Taufiq Ismail, Abrar Yusa, Afrizal Malna, Emha Ainun Nadjib, Heru Emka, W.S. Rendra and so on raised literature that breathed on religion.

Their works emphasize religious life as problem solvers not only as background. So do not be surprised if later emerged efforts to formulate their work as religious literature, Sufism, or literature that has a transcendental dimension [5]. This literary work is also known by various names such as enlightenment literature (Danarto), prophetic literature (Kuntowijoyo), Sufistic literature (Abdul Hadi WM), literary remembrance (Taufiq Ismail), literature involved in the inner world (M. Fudoli Zaini), transcendent literature (Sutardji Calzoum Bahri) and so on. These terms are rooted in the discourse of faith and religiosity that it carries [6]. Nevertheless basically is another interpretation of Islamic perspective literature that describes Islam by covering various aspects.

Seeing this tendency, in addition to having to acknowledge its presence, we must also provide a solid foundation for such literary genres to continue to develop in the future. The literary works basically originated in the traditions of Indonesian society that were formed thanks to the inclusion of Islam. Seyyed Hossen Nasr in Hadi [7] explained that tradition is not just customs or habits, ideas, and outlook on life but can also take the form of cultural expression, including art and culture, philosophical thought and various disciplines related to revelation or inspiration.

The conception study on Islamic literature was written by Sudardi and Hikmawati [8]. Unfortunately, the paradigm offered is still narrow. They are of the opinion that Islamic literature must hold fast to the aqeedah with the established Shari'a. Although it is explained that Islamic literature does not limit Arabic, the Indonesian context that is displayed is not too broad, not yet separated from the tradition of Arabic literature.

In another study, Kayo [9] explained that literature labeled Islam has a function as a defense against global civilization that is considered to attack Islam. Literature is considered capable of doing that because literature for a Muslim is not only a propaganda tool but the preaching itself. Literature is part of art, for that Asyari [10] explains the values and ethics of Islamic literature relating to art which in Islam does not only contain morals but also must be moral. Besides art in the view of Sayyed Housein Nars, intellectuals and academics from Iran, in the study of Binti A.Z. [11] Islamic art including literature is inspired by spiritual values which are the result of the embodiment of oneness in the religious field.

Based on the listener and literature review, the researcher tries to build a theoretical concept of modern Indonesian literature with a more comprehensive Islamic perspective

\section{Research Method}

This research is a qualitative descriptive study. Because of the theoretical nature of this research, the researcher reviewed available literature such as published books, journals, magazines, and research works as well as other sources related to the framework of Islamic values in modern Indonesian literature. A brief analysis and commentary on the available 
literature provides an overview of how Islamic perspectives in modern Indonesian literature are based on a system of values, practices of diversity, etc. as a theoretical framework. Data and information have been analyzed and carefully stated to make this study more informative and useful for people interested in this field.

\section{Results And Discussion}

To understand Indonesian literature with an Islamic perspective, previously it was necessary to understand modern Indonesian literature. Talking about modern Indonesian Literature certainly must be understood first the concepts associated with it. Various opinions explain several different meanings. Therefore, it is necessary to have various normative agreements on this understanding.

For this reason, it is formulated that modern Indonesian literature is literature printed in Latin letters in Malay which had developed towards the 20th century. Therefore, literary works written in Jawi letters and languages other than Malay do not enter modern Indonesian literature. The use of letters and writing became the boundary between old and modern literature [12].In literary treasures in Indonesia, there are literary works that were born and developed by various ethnic groups in the archipelago such as Acehnese, Sundanese Batak, Javanese, Balinese, Buginese, and so on. The characteristic that appears in the literature is the use of Mother tongue. Although the literature is not included as modern Indonesian literature, it is an element that supports and strengthens national culture. Some Indonesian authors such as Ajip Rosidi, in addition to writing in Indonesian, wrote a number of his works, especially at the beginning of his writing using his native language, Sundanese.

As the formulation is, modern Indonesian literature is Malay literature which is printed not only in the form of books but also works contained in press publications (newspapers and magazines) and books, both sought by the government and private publishers. Before independence, the colonial government had sought the publication of literary works through Balai Pustaka. The language in Balai Pustaka's works is the Malay language of the elite which was attempted to be spread by the colonial government through both schools and publishing [12].Whereas literary works outside the library use Popular Malay. The language is not a standard Malay language, but the Malay language that occurs because of the meeting between various nations and ethnic groups in the Archipelago which was originally only as an oral language [13]. Therefore, that language is also called Pasar Malay language. Apart from being a literary language, this language also becomes the language of newspapers because it lives and develops in society. This language is used in Popular Malay Literature.

Since the first novel of Lawah-Lawah Merah (1875) by Pont Jest, recorded for 100 years (1870-1960) this literature gave birth to 806 writers with 3005 works consisting of original drama, poetry, translations by Western authors, translations of Chinese stories, original novels and short stories. As many as 2757 authors can be identified, while 248 others are anonymous. These works are a reflection of the integration of the affluent into the culture of the archipelago and its assimilation. The sources of these works did not only come from Europe (France and the Netherlands) but also local sources (Makassar, Java, and Malay) who drew the social mirror of Indonesia at that time [14]. The writers of this work consisted of Europeans and Indo, Chinese and peranakans, and Indigenous people [15]. Compare with the literary works contained in modern Indonesian literature which are considered "official" during 1918- 
1967, there are only 175 writers with around 400 works. If counted until 1974, there were 284 authors and 770 works [16].

By looking at the facts, we must include Popular Malay Literature as Modern Indonesian Literature. Thus, Modern Indonesian Literature was not started by Balai Pustaka publications but was withdrawn back to the 1850s since the presence of Popular Malay Literary works. The concept is certainly open to debate by anyone, whether researchers, writers, or connoisseurs of literature.

Furthermore, to be able to define Modern Indonesian literature with an Islamic perspective, the concept of Islamic perspective must first be understood. Literature is a creative activity, a work of art [17]. Danziger and Johnson in Budianta et al. [18] see literature as a "language art", which is a branch of art that uses language as its medium. In this case it can be compared to the art of music, which processes sounds, dance that processes motion and fine arts that processes shapes and colors.

Art in Islam according to Nasr in A.Z. [11] contains at least three things, (1) reflecting religious values so that there is no such thing as secular art. There is no religious and secular dichotomy in Islam. Secular forces or elements in Islamic societies always have a religious understanding as does Divine law which specifically has a religious element. (2) Explain the spiritual qualities that are polite due to the influence of Sufism values. (3) There is a subtle and complementary relationship between the mosque and the palace, in terms of protection, use and function of art.

Therefore, art in Islam including literature is not only related to the material materials used but also the element of collective religious awareness that animates these material materials. Based on that, according to him the explanation of Islamic literature is based on these principles.

Sayyid Qutub in Mansur [19], explained that literary works in an Islamic perspective are works of art that express human reason and life that arise from the feelings of artists, namely expressions that emanate from human life and nature and human life with one another. This is in line with the opinion of Abdurahman Ra'faat Basya in Mansur[19], explaining that the expression of an author's art in expressing the reality of nature (al-kaun) and human life as a picture of Islamic teachings originating in Al-khaliq leads to the beginning of creatures. His. A similar opinion was conveyed by Said Hawa in Rosa [6]Islamic perspective literature is literature based on Islamic practice. Likewise, Ismail Raja Al Faruqi explained that art in Islam is the art of infiniti, where a form of art is accommodated in the belief in God.

However, if art is related or even limited to the things above, it will cause several things, namely (1) there is an interest in the form and content of the art; (2) there is a tension between loose art values and strict religious values; (3) limited space for art because it is used as part of religious practice; and (4) and disruption of freedom of governing religious norms.

For this reason, Ahmad [20] opinion can provide a broader understanding. He interprets literature in three ways: (1) literature produced by Muslims for humans; (2) literature produced by Muslims follows Islamic aesthetics for humans; and (3) literature produced by humans and in harmony with Islamic aesthetics for humans.

Thus, Islamic perspective of literature is a literary work that provides a picture of diversity both as a background and a life problem solver. Religion is based on a value system that includes faith, sharia, and ahlak which refers to the noble behavior and quality of character possessed by a good Muslim. It also involves all kinds of religious views and practices and traditions that develop in society that are not in conflict with Islam.

Based on this understanding, the scope of Islamic Literature [19] concerns the reality of the universe as its object. Everything in nature is a literary object. Literature is like a camera 
photographing this world with the correct picture, the results of which are exactly the same as those of Muslims.

The creatures and their relationship with the creator of the question can be a creative source of Islamic literature. Man's vertical relationship with Allah as the Khalifah of Allah on earth and relations with other creatures as individuals. Islamic literature can also include human love for all elements of family, relatives, all other human beings or others as he loves himself.Based on this, the scope of this literary work not only discusses the issue of Islamic creed or teachings but also the society contained in the novel which includes structure, dynamics, norms, and institutions. Thus, Islam in this literary genre is not only in the form of ideology, identity and way of life and thought of its characters and becomes an inherent part of the conflict but also as a socio-cultural background.

Literary works are born from literary figures who cannot escape from their existence as members of society. Literary works in this case, are evaluative writers' responses to the sociocultural conditions of the community [5]. For this reason, it is important to know the background of the author of Islamic perspective.

Referring to the understanding of Islamic Literature is literary literature produced by humans who follow the aesthetic of Islam for humans, Ahmad [20] argues that Islamic literature may be produced by anyone. Although he is not the author of Islam, following the aesthetics of Islam his work can be called an Islamic perspective of literature. The author of Islam might work against Islamic aesthetics.

Furthermore, Ahmad explained the quality of Islamic literature is not determined whether the author is Islamic or not. It is also not determined if he is Muslim whether the author is working in harmony or not. The value of Islamic work lies in his outlook on life, his talents, his character, his life experience, and his understanding of life.

Literary works are basically the results of writers' reflections to express what was seen and heard or felt imaginatively using the medium of language. In this context it can also be said that literature, more specifically, novels, are imaginative-creative results. Literature is inseparable from the empirical reality of its author. Literary work is not only imaginativecreative, but actually it is also an outcome to organize and get a new description of experiences that can only be imagined in the real world.

So, even though the novel is very personal, in a way it is a reflection of the author's experience in social life [21]. As members of the community, writers naturally have opinions on important social and political issues and follow the issues of the times [17].

The author's experiences and opinions about life are then lived, interpreted, and interpreted [22]. The result is then poured through the medium of language after being peppered with imagination into a literary work in the form of novels, poetry, and drama. Therefore, anyone can write a literary work with an Islamic perspective and the quality of this literary work is not determined by the level of Islam but by the quality of the work he wrote.

\section{Conclusion}

The writing of literary works that describe the life of Islam has begun since the beginning of modern Indonesian literature. In the next period, the works of this type are increasingly written so that it is necessary to formulate concepts of modern Indonesian literature with an Islamic perspective for the theoretical foundation for the development of this genre. The findings of this study explain that literary works with Islamic perspectives do not limit the 
creed or belief but it involves all ways of life and socio-cultural backgrounds. For this reason, this literature concerns all matters concerning Islam which includes people, society, religious practices, and traditions that develop in society that are not contrary to Islamic teachings. While this literary writer does not have to be a Muslim writer, anyone can write this type of literary work based on his views and life experiences.

\section{References}

[1] Atmosuwito, Subijantoro, Perihal Sastra dan Religiusitas Sastra. Bandung: Sinar Baru Algesindo, 2010.

[2] Mangunwijaya, Y.B., Sastra dan Religiositas Sastra. Jakarta: Kanisius, 1994.

[3] Sayuti, Suminto A., "Citra Estetik Islam dalam Sajak-sajak Indonesia Mutakhir: Beberapa Catatan Awal," in Adakah Bangsa dalam Sastra?, Jakarta: Pusat Bahasa, 2007, p. 177.

[4] Muhamad, Goenawan, "Perihal Sastra Islam," in Sumber Terpilih Sejarah Sastra Abad XX, Ulrich E. Kratz, Ed. Jakarta: Gramedia, 2006, pp. 549--550.

[5] Mahayana, Maman S., 9 Jawaban Sastra Indonesia. Sebuah Orientasi Kritik. Jakarta : Bening, 2005.

[6] Rosa, Helvy Tiana, Segenggam Gumam: Esai-esai tentang Sastra dan Kepenulisan. Bandung: Syamil Cipta Media, 2003.

[7] Hadi, Abdul, Kembali ke Akar Kembali ke Sumber. Jakarta: Pustaka Firdaus, 1999.

[8] Sudardi, Bani dan Hanifah Hikmawati, "Perkembangan Konsep Sastra Islam," Haluan Sastra Budaya, vol. xxxv, no. 6, pp. 27--35, 2016.

[9] Kayo, Fadillah, "Mempermasalahkan 'Sastra Berlabel Islam' Menghadapi Peradaban Global," Jurnal Ilmu Budaya, vol. 3, no. 2, pp. 14--21, 2007.

[10] Asy’ari, M., "Islam dan Seni," Hunafa: Jurnal Studia Islam, vol. 4, no. 2, pp. 169--174, 2007.

[11] A.Z, Siti Binti, "Spiritual dan Seni Islam menurut Sayyed Hoseen Nasr," Harmoni: Jurnal Pengetahuan. dan Pemikiran Seni, vol. 5, no. 3, 2005.

[12] Damono, Sapardi Djoko, Novel Indonesia Sebelum Perang. Jakarta: Pusat Pembinaan dan Pengembangan Bahasa, 1979.

[13] Toer, Pramodya Ananta, Tempo Doeloe: Antolog Sastra Pra-Indonesia. Jakarta: Lentera Dipantra, 2003.

[14] Budianta, Melani, "Sastra Indonesia Awal: Kontribusi Orang Tionghoa by Caludine Salmon.," in Bidjen toot de Taal-, Land- en Volkenkunde, 2012, p. 148.

[15] Salmon, Claudine, Sastra Indonesia Awal: Kontribusi Orang Tionghoa. Jakarta: Gramedia, 2011.

[16] Teeuw, A., Sastra dan Ilmu Sastra: Pengantar Teori Sastra. Jakarta: Pustaka Jaya, 1988.

[17] Wellek, Rene dan Austin Waren, Teori Kesustraan. Jakarta: Gramedia, 1995.

[18] Budianta, Melani dkk, Membaca Sastra. Magelang: Tera, 2006.

[19] Manshur, Fadlil Munawar, Perkembangan Sastra Arab dan Teori Sastra Islam. Yogyakarta: Pustaka Pelajar, 2011.

[20] Ahmad, Kassim and Shahnon Ahmad, Polemik Sastra Islam. Kualumpur: Dewan Bahasa dan Pustaka, 1987.

[21] Abdulah, Taufiq, "Sastra dan Sejarah: Pantulan Historis dan Novel," Horison, Jakarta, pp. 502-507, 1983.

[22] K. Saddhono, N. E. Wardani, and C. Ulya. "Sociopragmatic approach on discourse structure of friday prayer's sermon in java and madura island." J. of Lang and Lit, vol. 6 no. 1 pp 26-29, 2015. 